\title{
Wind effects on leaf morphology for the mangrove Conocarpus erecta at an oceanic island from the Mexican Pacific Ocean
}

\author{
Efectos del viento en la morfología foliar del mangle Conocarpus erecta en una isla \\ océanica del Pacífico mexicano
}

ERICK DE LA BARRERA ${ }^{1, *} \&$ HARTMUT S. WALTER ${ }^{2}$

${ }^{1}$ Department of Organismic Biology, Ecology, and Evolution, University of California, Los Angeles, California 90095-1606, USA

Present address: Centro de Investigaciones en Ecosistemas, Universidad Nacional Autónoma de México, Apartado Postal 27-3, Morelia, México 58089

${ }^{2}$ Department of Geography, University of California, Los Angeles, California 90095-1524, USA

*e-mail for correspondence: erick@oikos.unam.mx

\begin{abstract}
Leaf morphology was measured and aerodynamical attributes as well as transpiration rates were calculated for the mangrove Conocarpus erecta from sites naturally sheltered or sites exposed to oceanic winds at Socorro Island, Mexico, and compared with those of C. erecta, Laguncularia racemosa, and Rhizophora mangle at a mainland estuary near La Manzanilla, Jalisco, Mexico. Leaves of C. erecta, $5.98 \mathrm{~cm}$ in length and $2.03 \mathrm{~cm}$ in width, were the smallest and most streamlined of the mainland mangroves. Moreover, both leaf dimensions were $32 \%$ smaller for trees from the exposed sites on Socorro Island than on the mainland. For a given wind velocity, Reynolds numbers were 10 to $33 \%$ lower at Socorro Island than on the mainland for leaves of $C$. erecta, leading to a 17 to $45 \%$ lower drag force exerted by wind on such leaves. Reynolds numbers characterize the degree of turbulence of a fluid moving adjacent to the surface of an object; here such a dimensionless number was used as a measure of fluttering for leaves. Transpiration rates for $C$. erecta were $25 \%$ lower for plants growing at exposed sites on Socorro Island than on the sheltered sites, whose midday

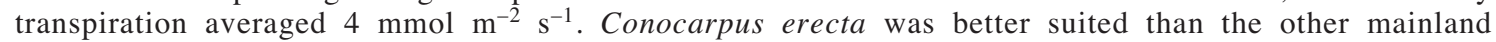
mangroves to windy environments owing to its smaller and more streamlined leaves. The population from Socorro Island underwent further morphological changes in response to wind at exposed sites, explaining, in part, the presence of this species and not of other mangroves on this oceanic Pacific island.
\end{abstract}

Key words: energy balance, hurricane damage, island biogeography, Laguncularia racemosa, Reynolds number, Rhizophora mangle.

\section{RESUMEN}

Se midió la morfología foliar y se calcularon atributos aerodinámicos además de tasas potenciales de transpiración del mangle Conocarpus erecta en sitios naturalmente protegidos y expuestos al viento oceánico en la Isla Socorro, México, y de C. erecta, Laguncularia racemosa y Rhizophora mangle en un estuario continental cerca de La Manzanilla, Jalisco, México. Se realizaron comparaciones entre especies y sitios. Las hojas de $C$. erecta, de $5,98 \mathrm{~cm}$ de longitud y 2,03 de ancho, fueron las más pequeñas y aerodinámicas de los mangles del continente. Más aún, ambas dimensiones foliares fueron $32 \%$ más pequeñas para los árboles de los sitios expuestos en la Isla Socorro que en el continente. Para cualquier velocidad del viento, el número de Reynolds fue 10 a $33 \%$ menor en Isla Socorro que para las hojas de C. erecta en el continente, por lo que el viento ejerce una fuerza de arrastre 17 a $45 \%$ menor para las primeras. El número de Reynolds caracteriza la turbulencia de un fluido que se mueve adyacente a una superficie; aquí se utilizó dicho número adimensional como medida del revoloteo de las hojas. La tasa de transpiración de C. erecta en Isla Socorro fue $25 \%$ menor para las plantas de sitios expuestos que para aquellas de sitios protegidos, cuya transpiración promedió 4 mmol m${ }^{-2} \mathrm{~s}^{-1}$ al medio día. Conocarpus erecta presentó mejores características para ambientes con viento debido a que sus hojas son más pequeñas y aerodinámicas. La población de Isla Socorro presentó mayores cambios morfológicos en respuesta al viento en sitios expuestos, explicando, en parte, la presencia de esta especie y no de otros manglares en esta isla océanica.

Palabras clave: balance de energía, biogeografía de islas, daño por huracán, Laguncularia racemosa, número de Reynolds, Rhizophora mangle. 


\section{INTRODUCTION}

Mangrove forests are distributed along tropical shores around the world, occurring at the interface between land and ocean where they facilitate the development of numerous lifeforms (Lugo \& Snedaker 1974, LaraDomínguez \& Yañez-Arancibia 1999). But mangroves are exposed to a suite of distinct environmental stresses. For instance, increased salt content in the soil (Passioura et al. 1992, Medina 1999) and water logging (Ellison \& Farnsworth 1997) may decrease the productivity of mangroves, and limit their distribution (Jiménez 1984). Mangrove forests are especially susceptible to damage by the high wind velocities of hurricanes, often with catastrophic consequences (Balwin et al. 2001). Vulnerability to hurricanes is greater for plant communities from oceanic islands, where the topography may provide less shelter than at mainland locations and the frequency and/or severity of hurricanes may also be relatively higher. Furthermore, because oceanic islands are located at considerable distances from the mainland, the vulnerability of island biotas to catastrophic disturbances is exacerbated because the dispersal of propagules from the mainland is difficult (Ricklefs 1979). Nevertheless, stable biotas not only persist and even thrive on small oceanic islands (Walter 1998), but also are often the object of remarkable evolutionary departures from their mainland counterparts.

When exposed to high-wind environments, plants may reduce their height (Cleugh et al. 1998, Nobel 2005), the size of their leaves (Whitehead \& Luti 1962, Nobel 1981), and the size of their propagules for wind-dispersed species (Cody \& Overton 1996). Additionally, leaf morphology may change in response to wind (Vogel 1981, 1989). Decreases in plant height and leaf size can be accompanied by a reduction in productivity, reflected by a decrease in dry mass accumulation and/or net $\mathrm{CO}_{2}$ uptake rates (Nobel 1981, Cleugh et al. 1998, Medina 1999).

Morphological adaptations to wind were studied for Conocarpus erecta growing at locations with different wind exposure at Socorro Island, and for C.erecta, Laguncularia racemosa, and Rhizophora mangle from $\mathrm{La}$ Manzanilla, Jalisco, a mainland estuary of similar latitude on the Pacific coast of Mexico (Fig. 1). In particular, leaf dimensions and morphology were determined and some aerodynamical attributes were calculated as a function of wind velocity. Additionally, potential transpiration rates were calculated based on leaf morphology and prevailing microenvironmental conditions in the field. Because plants from oceanic islands are exposed to high wind environments, with frequent hurricane events, and because only $C$. erecta is found on Socorro Island, the following hypotheses were tested: (1) Leaves of $C$. erecta are more streamlined than those of the other mangrove species found on the mainland; (2) the leaves of $C$. erecta from Socorro Island, are in turn, smaller and more streamlined than for its mainland conspecific, especially for those individuals growing at locations with high wind exposure.

\section{MATERIAL AND METHODS}

\section{Study sites and species}

Socorro Island $\left(18^{\circ} 43^{\prime} \mathrm{N}, 110^{\circ} 57^{\prime} \mathrm{W}\right)$, with an area of $140 \mathrm{~km}^{2}$, is the largest of the four volcanic islands that comprise the Revillagigedo Archipelago in the Mexican Pacific Ocean (Fig. 1). The vascular flora of Socorro Island has approximately 117 species, $25 \%$ of which are endemics (Levin \& Moran 1989). Mean daily air temperatures at Socorro average $26{ }^{\circ} \mathrm{C}$ throughout the year (Fig. 2A). The annual precipitation is $761 \mathrm{~mm}^{\text {year }}{ }^{-1}, 80$ $\%$ of which occurs during the summer (Fig. 2B). The monthly maximum wind velocity averages $7 \mathrm{~m} \mathrm{~s}^{-1}$ throughout the year, except when hurricanes reach Socorro Island with wind velocities exceeding $20 \mathrm{~m} \mathrm{~s}^{-1}$ (Fig. 2C).

Conocarpus erecta (L.) Combretaceae (Wiggins 1980, Levin \& Moran 1989) is the only mangrove present in Socorro Island (Levin \& Moran 1989), where it occurs along the northern shores of the island. This species is sometimes regarded as a false mangrove due to the lack of pneumatophores and vivipary, although it is tolerant of high salinity and dry soils, tending to grow in association with other mangrove species (Tomlinson 1994).

The present study focused on the northernmost population, located at Playa Norte (also 
named Bahía Academy, Fig. 1), where C. erecta can be found from sea level to the hilltops, at elevations approaching $100 \mathrm{~m}$. Near the sea level, C. erecta occurs as a monoculture of 3-mtall trees. At elevations above $10 \mathrm{~m}$, the euphorb tree Hippomane mancinella also becomes part of the canopy. Tree height gradually decreases for both species at elevations above $25 \mathrm{~m}$. At elevations above $50 \mathrm{~m}$, the shrub Dodonaea viscosa (Sapindaceae), which is widely distributed on Socorro Island (Levin \& Moran 1989, E. De la Barrera unpublished results), becomes an important component of plant cover. At the hilltops near $100 \mathrm{~m}$ in elevation, most of the plant cover is from herbaceous species; woody plants become infrequent and their height

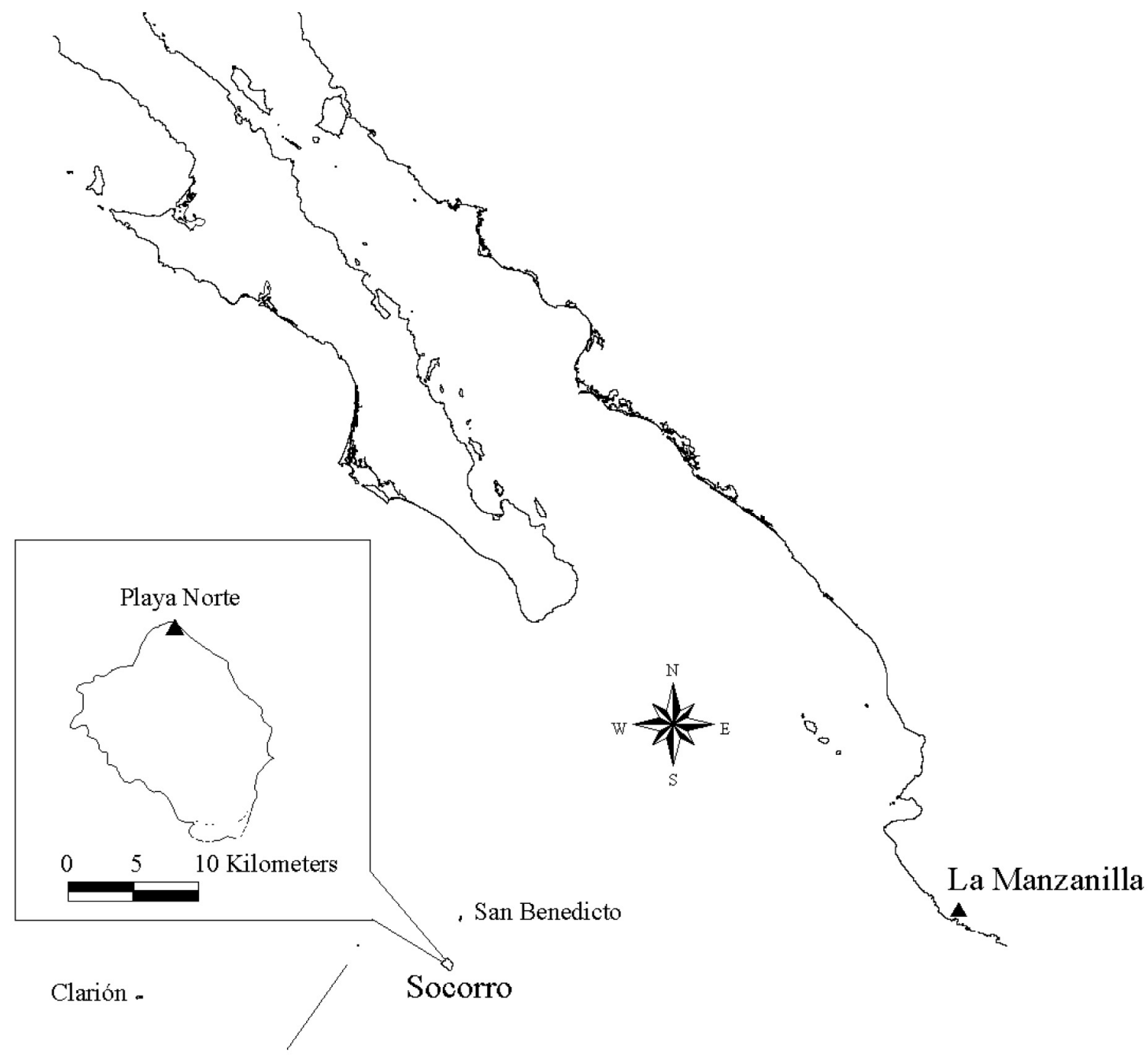

Roca Partida

$0 \quad 250 \quad 500$ Kilometers

Fig. 1: Map of the western coast of Mexico showing the study sites (triangles) at Socorro Island $\left(18^{\circ} 43^{\prime} \mathrm{N}, 110^{\circ} 57^{\prime} \mathrm{W}\right)$ and La Manzanilla, Jalisco $\left(19^{\circ} 17^{\prime} \mathrm{N}, 104^{\circ} 47^{\prime} \mathrm{W}\right)$. The base map of Mexico is courtesy of the Comisión Nacional para el Conocimiento y Uso de la Biodiversidad (1998).

Mapa de la costa occidental de México en el que se muestran los sitios de estudio (triángulos) en Isla Socorro ( $10^{\circ} 43^{\prime} \mathrm{N}$, $110^{\circ} 57^{\prime}$ O) y La Manzanilla, Jalisco ( $19^{\circ} 17^{\prime} \mathrm{N}, 104^{\circ} 47^{\prime} \mathrm{O}$ ). El contorno del mapa de México es cortesía de la Comisión Nacional para el Conocimiento y Uso de la Biodiversidad (1998). 
does not exceed $1.5 \mathrm{~m}$. Playa Norte is exposed to very high wind velocities, as evidenced by trees of $H$. mancinella at the hilltops, for which trunk diameter exceeded $30 \mathrm{~cm}$, trunk length exceeded $3 \mathrm{~m}$, but which only grew vertically up to $1.5 \mathrm{~m}$, and thereafter grew horizontally adjacent to the ground (E. De la Barrera unpublished results). Indeed, plant shapes at the hilltop were reminiscent of Krumholtz vegetation.
On 17-19 May 1999, individual trees of $C$. erecta were studied at sites from Playa Norte with different exposure to oceanic winds. In particular, sheltered trees were studied near sea level ("0 m"), approximately $21 \mathrm{~m}$ inland into a ravine separating two $\sim 100$-m-high hills that connects the ocean with a seasonal flood plain, and on a North-facing slope at $50 \mathrm{~m}$ in elevation, which is sheltered from direct oceanic exposure

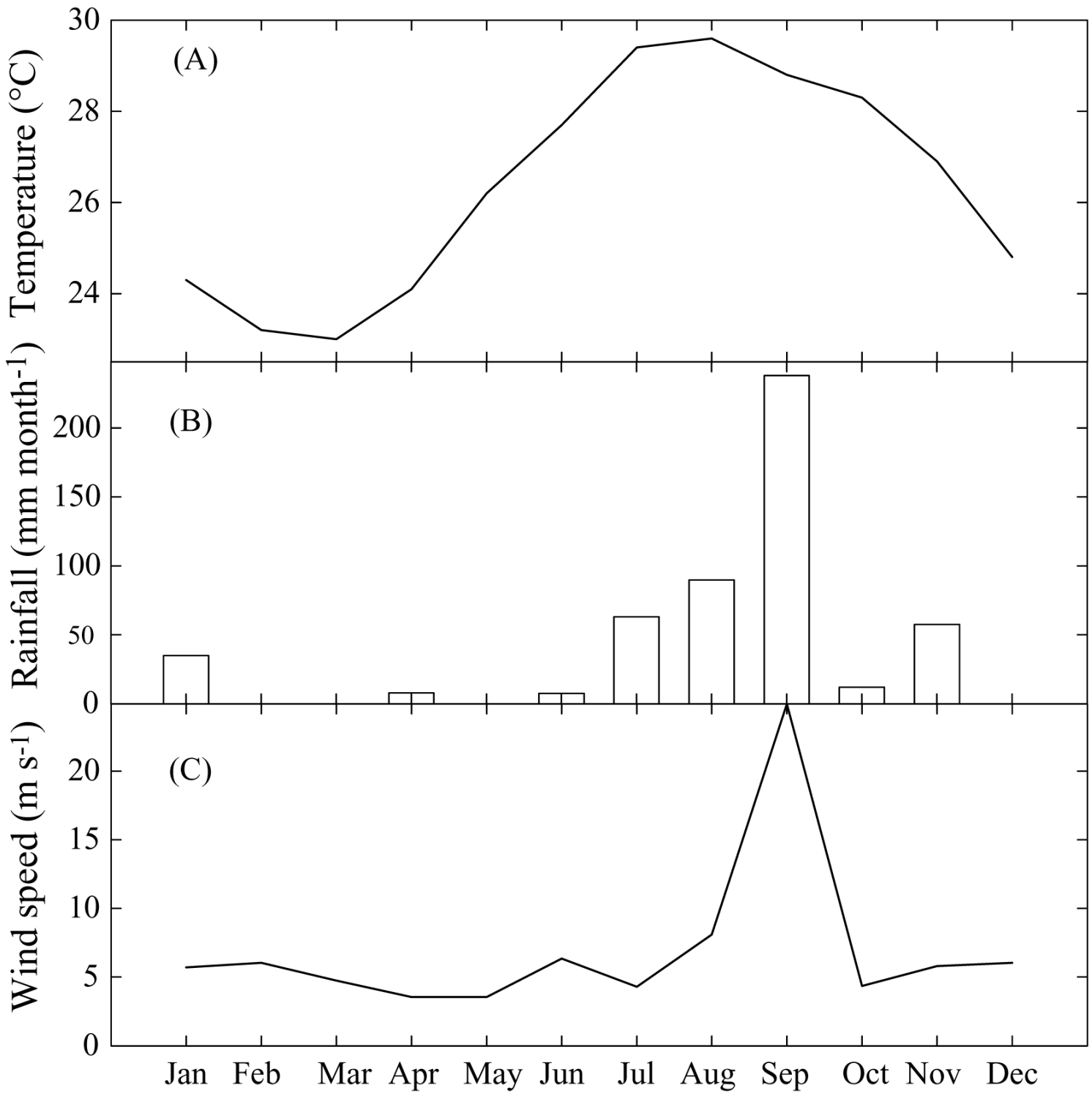

Fig. 2: Climate of Socorro Island. Air temperature (A) and precipitation (B) were redrawn from Medina (1978). Wind velocity (C) represents means for 1997 and 1998, provided by the Comisión Nacional del Agua and Secretaría de Marina weather station from Socorro Island.

Clima de Isla Socorro. La temperatura del aire (A) y la precipitación (B) fueron dibujadas a partir de Medina (1978). La velocidad del viento (C) es el promedio de los registros de 1997 y 1998, que fueron proporcionados por la estación meteorológica de Isla Socorro, adscrita a la Comisión Nacional del Agua y la Secretaría de Marina. 
by a neighboring hill ("50 m-sheltered"). Trees exposed to oceanic winds were studied at $50 \mathrm{~m}$ in elevation on a North-facing slope that was directly facing the ocean ("50 m-exposed") and near $100 \mathrm{~m}$ in elevation on a horizontal hilltop ("100 m"). Actual differences in wind velocity could not be measured because these occur during the summer hurricane season, a time when the Mexican military authority does not allow visits to the island, especially the north shore, for safety reasons.

On 21 April 1999, mangroves were also studied at a mainland estuary near La Manzanilla, Jalisco (19 $17^{\prime}$ N, $104^{\circ} 47^{\prime}$ W, Fig. 1 ), where the mangrove forest occurs along an estuary connected to the Pacific Ocean through a south-facing bay, for which surrounding mountains provide shelter from oceanic winds. The species present at this low-wind location, namely $C$. erecta, Laguncularia racemosa, and Rhizophora mangle, were compared with the mangrove from Socorro Island as a control to compare wind effects on the island.

Laguncularia racemosa (L.) Gaertn.f. (Combretaceae) is a species native to America and west Africa, it has opposite and fleshy leaves suited with salt excreting glands on the upper side of the petiole, near the leaf blade (Tomlinson 1994). At La Manzanilla this species occurs closest to the water in association with $C$. erecta (Hernández-Vázquez 2000). Besides these two species, R. mangle can be found in more inland sections of this mangrove forest (Hernández-Vázquez 2000). Commonly known as red mangrove, $R$. mangle is a species of ample tropical distribution, from western Africa to the Pacific coast of America, that has dark green leaves and whose propagules germinate before leaving the mother plant (Tomlinson 1994).

\section{Leaf morphology}

For each species considered at La Manzanilla and for each study site at Socorro Island, 10 east-facing terminal branches were detached at mid-height from different individuals; their leaves were removed with a razor blade, pooled for each site or species, and visually sorted by length. Leaf length $(l)$ and maximum leaf width $(w)$, usually occurring at mid-leaf, were measured with a vernier caliper (gradations of $0.02 \mathrm{~mm}$ ) for the longest 100 fully developed leaves. The longest leaves were used because leaf aerodynamical attributes depend on leaf dimensions (see below), so their properties indicate the greatest possible interaction with wind. Assuming that the leaves were ellipses, their eccentricity, a dimensionless parameter that equals 0 for a circle and increases as the ellipse becomes more oblong, was calculated as $\left\{1-\left[(0.5 w)^{2} /(0.5 l)^{2}\right]\right\}^{0.5}$ (Eves 1967).

\section{Leaf aerodynamics}

Leaf aerodynamical attributes were calculated as a function of wind velocity $(s)$ for the mangroves from La Manzanilla and for C. erecta from Socorro Island. In particular, the Reynolds number, a dimensionless variable that reflects turbulent versus laminar flow adjacent to the surface of an object, was calculated for mangrove leaves as ( $s l / v$ ) (Vogel 1981, Nobel 2005); where, $v$, the kinematic viscosity of air, was assumed to be $1.552 \times 10^{-5} \mathrm{~m}^{2} \mathrm{~s}^{-1}$, as for dry air at $25{ }^{\circ} \mathrm{C}$ (Nobel 2005). Essentially, a higher value of Reynolds number indicates that a leaf will be subjected to more fluttering than a leaf with a lower value. The drag force exerted by wind on mangrove leaves was calculated as $0.5\left(c_{d} \rho A s^{2}\right)$ (Vogel 1981, Nobel 2005); where $c_{d}$ is the drag coefficient-values of 1.1 and 0.013 were chosen to respectively assess the extreme situations of a leaf positioned perpendicular and of a leaf positioned parallel to the direction of the wind (Vogel 1981), although $c_{d}$ values measured for different leaves, which can change their position and undergo morphological adjustments as wind speed increases, usually range between 0.05 and 0.1 (Vogel 1989); $\rho$ is the air density, e.g., $1.186 \mathrm{~kg} \mathrm{~m}^{-3}$ for dry air at $25{ }^{\circ} \mathrm{C}$ (Nobel 2005); and $A$ is the area of a leaf, $[\pi(0.5 l)(0.5 w)]$, as for an ellipse. Finally, the mean boundary layer thickness was calculated for mangrove leaves as $4(l / s)^{0.5}$ (Nobel 2005).

\section{Water relations}

Stomatal frequency $(n)$ and stomatal dimensions were determined for leaves of $C$. erecta from La Manzanilla. A thin coat of clear nail-polish was applied to the adaxial (upper) and the abaxial (lower) surfaces of leaves and allowed to dry before it was carefully removed and placed in small paper envelopes until processing. The stomatal impressions so 
obtained were examined at the University of California, Los Angeles, California, USA, using a BH-2 light microscope (Olympus, Lake Success, New York, USA). Stomatal frequency was determined for five fields of view totaling $8.25 \mathrm{~mm}^{2}$ for each leaf impression. Stomatal pore length and width (averaged to obtain the mean pore radius, $r$ ), as well as guard cell width $(\delta s t)$, were measured for 20 stomates from each of five leaf impressions.

On 17-18 May 1999, air temperature and relative humidity were measured at Socorro Island every $2 \mathrm{~h}$ over a $24-\mathrm{h}$ period with a thermohygrometer (Forestry Suppliers, Jackson, Mississippi, USA). Based on the environmental conditions prevalent at each time of measurement, the daily pattern of the vapor pressure difference $(V P D)$ between the leaves of $C$. erecta and the surrounding air was determined, assuming that leaves were at water vapor saturation and at the same temperature as the air (Rundel \& Jarrell 1989, Nobel 2005).

Potential transpiration rates for leaves of $C$. erecta were modeled, based on Fick's first law of diffusion, as $\frac{\pi D_{w v} n r^{2} V P D}{R T \delta_{s t}}$ (Nobel 2005), where, $D w v$ is the diffusion coefficient of water vapor, $2.50 \times 10^{-5} \mathrm{~m}^{2} \mathrm{~s}^{-1}$ at $25{ }^{\circ} \mathrm{C}$; and, $R T$ is the product of the gas constant and the absolute air temperature, e.g., $2.479 \mathrm{~m}^{3} \mathrm{kPa} \mathrm{mol}^{-1}$ at $25{ }^{\circ} \mathrm{C}$.

\section{Statistical analyses}

Statistical analyses were performed with JMPIN-4.03 (SAS Institute, Cary, North Carolina, USA). Data are shown as mean $\pm \mathrm{SE}(\mathrm{n}=$ sample size).

\section{RESULTS}

\section{Leaf morphology}

For the mangroves from La Manzanilla (the study site on the mainland), leaf length and width differed between the three species considered $(\mathrm{P}<0.05$ from pairwise Tukey tests, following a one-way ANOVA). Conocarpus erecta had the smallest leaves and Rhizophora mangle had the largest leaves (Table 1). Leaf eccentricity was higher for $C$. erecta than for the other two species from La Manzanilla $(\mathrm{P}<0.05$,
Table 1). On Socorro Island, leaf dimensions for C. erecta were reduced for the plants growing at locations with increased wind exposure relative to those from sheltered locations (Table 1). For instance, leaf length and width were respectively $33 \%$ and $20 \%$ less at $100 \mathrm{~m}$ in elevation than at sea level, where the leaf length was $5.98 \mathrm{~cm}$ and the leaf width was $2.03 \mathrm{~cm}(\mathrm{P}<0.05$, Table 1$)$. Leaf eccentricity for $C$. erecta from Socorro Island was greater for those plants growing at the two sheltered sites than for those growing at the exposed locations $(\mathrm{P}<0.05$, Table 1$)$.

\section{Leaf aerodynamics}

Leaf aerodynamical attributes were different among the three mangrove species studied at La Manzanilla (Fig. 3). In particular, the Reynolds number, here utilized to quantify potential leaf fluttering, was 50,000 for $R$. mangle at $7 \mathrm{~m} \mathrm{~s}^{-1}$ (the annual average of maximum wind velocity at Socorro Island, Fig. 2 ), decreasing by $30 \%$ for L. racemosa and by $42 \%$ for C. erecta (Fig. 3A). Similarly, the drag force exerted by wind on mangrove leaves was greatest for $R$. mangle, amounting to $0.6 \mathrm{~N}$ for leaves positioned perpendicular to wind blowing at $7 \mathrm{~m} \mathrm{~s}^{-1}$ (Fig. 3B), and to $7 \times 10^{-3} \mathrm{~N}$ for leaves parallel to wind blowing at $7 \mathrm{~m} \mathrm{~s}^{-1}$ (Fig. 3C). The mean boundary layer thickness, which can influence the water vapor conductance at low wind velocities (Grace 1974, Nobel 2005), was greatest for $R$. mangle, it was $17 \%$ thinner for L. racemosa and $24 \%$ thinner for C. erecta (Fig. 3D).

The leaves of $C$. erecta from exposed sites from Socorro Island were smaller and more streamlined than those from La Manzanilla $(\mathrm{P}<$ 0.05 , Fig. 4, Table 1). For any given wind velocity, Reynolds numbers for leaves of $C$. erecta were $10 \%$ lower at the sheltered locations on Socorro island than at $\mathrm{La}$ Manzanilla, and $33 \%$ lower at the exposed locations (Fig. 4). The drag force exerted by wind on the leaves of $C$. erecta from Socorro Island averaged $17 \%$ less at the sheltered locations and $45 \%$ less at the exposed locations than at La Manzanilla (Fig. 4). With respect to the mean boundary layer thickness, it was $5 \%$ thinner at the sheltered sites and $17 \%$ thinner at the exposed sites of Socorro Island, than it was at La Manzanilla for a given wind velocity (Fig. 4). 


\section{TABLE 1}

Leaf morphology for mangrove species from La Manzanilla and Socorro Island. Data shown are means \pm SE $(n=100$ leaves for each species at La Manzanilla or from each of the four sites at Socorro Island). For each column, different letters indicate statistical difference at $\mathrm{P}<0.05$, from pairwise Tukey tests following a one-way ANOVA

Morfología foliar de mangles de La Manzanilla e Isla Socorro. Los datos mostrados son promedios \pm EE ( $n=100$ hojas para cada especie de La Manzanilla o de cada uno de los cuatro sitios en Isla Socorro). Para cada columna, letras distintas indican diferencias estadísticas con $\mathrm{P}<0,05$ a partir de pruebas de Tukey realizadas después de un ANDEVA de una vía

\begin{tabular}{|c|c|c|c|}
\hline Site & Leaf length $(\mathrm{cm})$ & Leaf width $(\mathrm{cm})$ & Leaf eccentricity (dimensionless) \\
\hline \multicolumn{4}{|l|}{ La Manzanilla } \\
\hline Conocarpus erecta & $6.96 \pm 0.13^{\mathrm{a}}$ & $2.33 \pm 0.04^{\mathrm{a}}$ & $0.940 \pm 0.002^{\mathrm{a}}$ \\
\hline Laguncularia racemosa & $8.42 \pm 0.58^{b}$ & $3.15 \pm 0.09^{b}$ & $0.914 \pm 0.004^{\mathrm{b}, \mathrm{c}}$ \\
\hline Rhizophora mangle & $12.09 \pm 0.25^{\mathrm{c}}$ & $4.75 \pm 0.10^{\mathrm{c}}$ & $0.919 \pm 0.001 \mathrm{~b}, \mathrm{~d}$ \\
\hline \multicolumn{4}{|l|}{ Socorro Island } \\
\hline \multicolumn{4}{|l|}{ Conocarpus erecta } \\
\hline $0 \mathrm{~m}$ & $5.98 \pm 0.12^{a}$ & $2.03 \pm 0.05^{\mathrm{d}, \mathrm{e}}$ & $0.938 \pm 0.002^{\mathrm{a}}$ \\
\hline $50 \mathrm{~m}$ sheltered & $6.43 \pm 0.34^{\mathrm{a}}$ & $2.24 \pm 0.05^{\mathrm{a}, \mathrm{e}}$ & $0.924 \pm 0.003^{\mathrm{a}, \mathrm{b}}$ \\
\hline $50 \mathrm{~m}$ exposed & $4.73 \pm 0.14^{\mathrm{d}}$ & $1.91 \pm 0.04^{\mathrm{d}}$ & $0.897 \pm 0.008^{c}$ \\
\hline $100 \mathrm{~m}$ & $4.65 \pm 0.13^{\mathrm{d}}$ & $1.86 \pm 0.05^{\mathrm{d}}$ & $0.907 \pm 0.005^{\mathrm{c}, \mathrm{d}}$ \\
\hline
\end{tabular}

\section{Water relations}

Stomatal frequency averaged $16 \mathrm{~mm}^{-2}$ for the leaves of $C$. erecta from La Manzanilla (Table 2), being $30 \%$ greater for the abaxial (lower) surface than for the adaxial (upper) surface (P $<0.05$ Student's t-test; Table 2). The mean stomatal radius, which averaged $97 \mu \mathrm{m}$, was 13 $\%$ longer for the stomates on the abaxial surface than it was for stomates on the adaxial surface of leaves $(\mathrm{P}<0.05$, Table 2$)$. Guard cell width averaged $6.5 \mu \mathrm{m}$ for both sides of the leaves of C. erecta (Table 2).

On 17-18 May 1999, air temperature at Socorro Island ranged from $14.4{ }^{\circ} \mathrm{C}$ at $04 \mathrm{~h}$ to $27.8{ }^{\circ} \mathrm{C}$ at $14 \mathrm{~h}$, averaging $24.0{ }^{\circ} \mathrm{C}$ during the day (Fig. 5A). Relative humidity was greater at night than during the day, the maximum of 81 $\%$ occurred at $02 \mathrm{~h}$ and the minimum of $49 \%$ occurred at $16 \mathrm{~h}$ (Fig. 5A). Such environmental conditions led to vapor pressure differences between the leaves and the surrounding air that ranged from $0.4 \mathrm{kPa}$ at $02 \mathrm{~h}$ to $1.7 \mathrm{kPa}$ at $16 \mathrm{~h}$ (Fig. 5B). The potential transpiration rates that were calculated for leaves of $C$. erecta were lower for the plants growing on locations with higher wind exposure (Fig. 5C). For instance, the maximum transpiration rate, from 12 to 16 $\mathrm{h}$, was $4 \mathrm{mmol} \mathrm{m}^{-2} \mathrm{~s}^{-1}$ for plants growing at sea level, decreasing by $25 \%$ for those growing at $100 \mathrm{~m}$ in elevation $(\mathrm{P}<0.05$, Fig. $5 \mathrm{C})$.

\section{DISCUSSION}

Conocarpus erecta appeared to be better suited to high-wind environments than the other mangroves studied at La Manzanilla, owing to the fact that its leaves had a smaller area and were more streamlined than the leaves of Laguncularia racemosa or Rhizophora mangle. This may explain, at least partially, why $C$. erecta, and not the other mangroves, is found on Socorro Island, although, obviously, other factors such as the natural history for species dispersal should be considered. The lower Reynolds numbers found for leaves of C. erecta suggest that their blades have a morphological specialization for reduced fluttering, a difference that was more prominent for the 


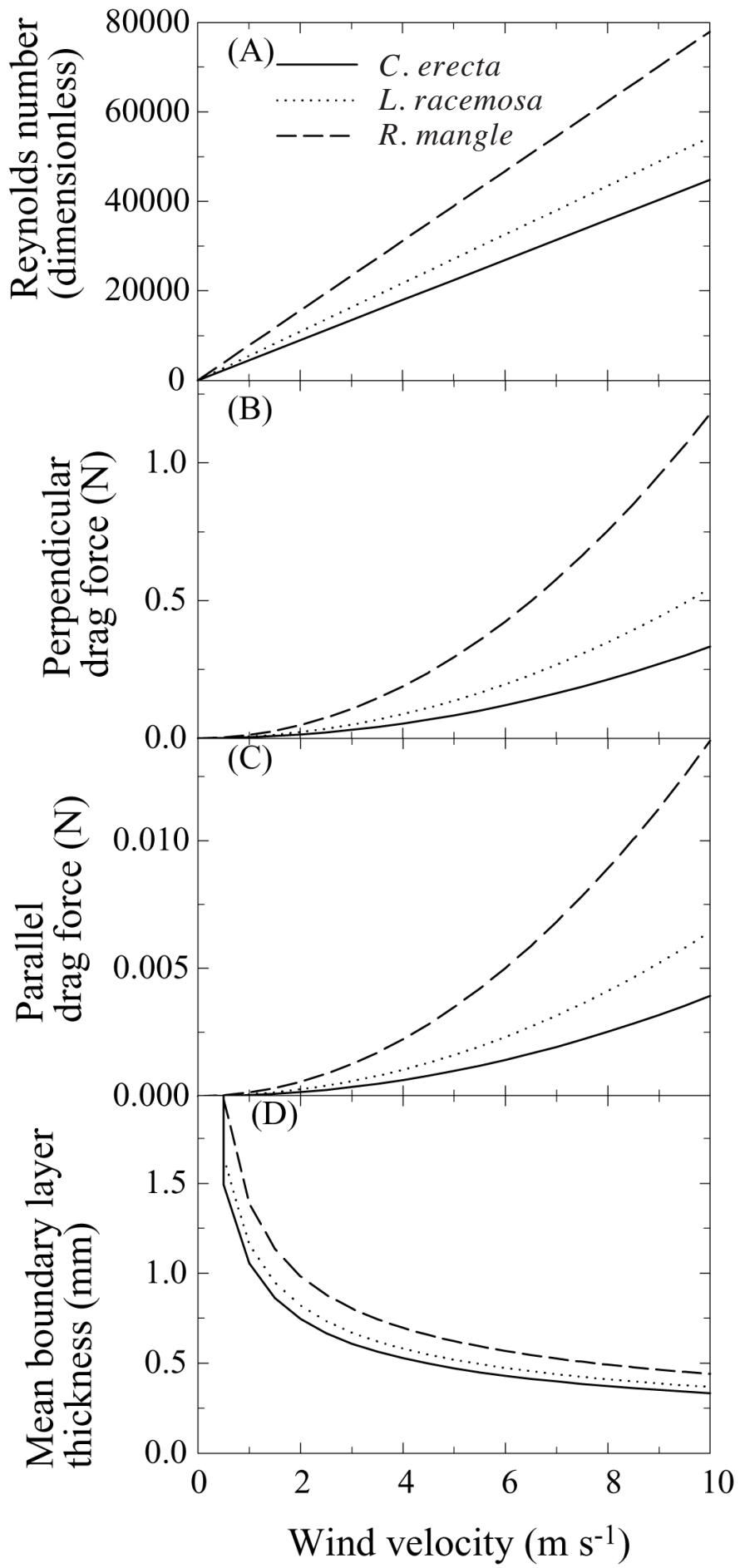

Fig. 3: Leaf aerodynamics for mangroves from La Manzanilla, Jalisco: (A) Reynolds number, (B) drag force exerted by wind on leaves positioned perpendicular to the flow direction, (C) drag force exerted by wind on leaves aligned with the flow direction, and (D) mean boundary layer thickness. Data, shown as a function of wind velocity, were calculated based on leaf morphology.

Aerodinámica foliar en manglares de La Manzanilla, Jalisco: (A) número de Reynolds, (B) fuerza de arrastre que el viento ejercería en hojas colocadas de manera perpendicular a la dirección de flujo, (C) fuerza de arrastre que el viento ejercería en hojas colocadas de manera paralela a la dirección de flujo, y (D) grosor promedio de la capa límite. Los datos, mostrados como una función de la velocidad del viento, fueron calculados a partir de la morfología foliar. 

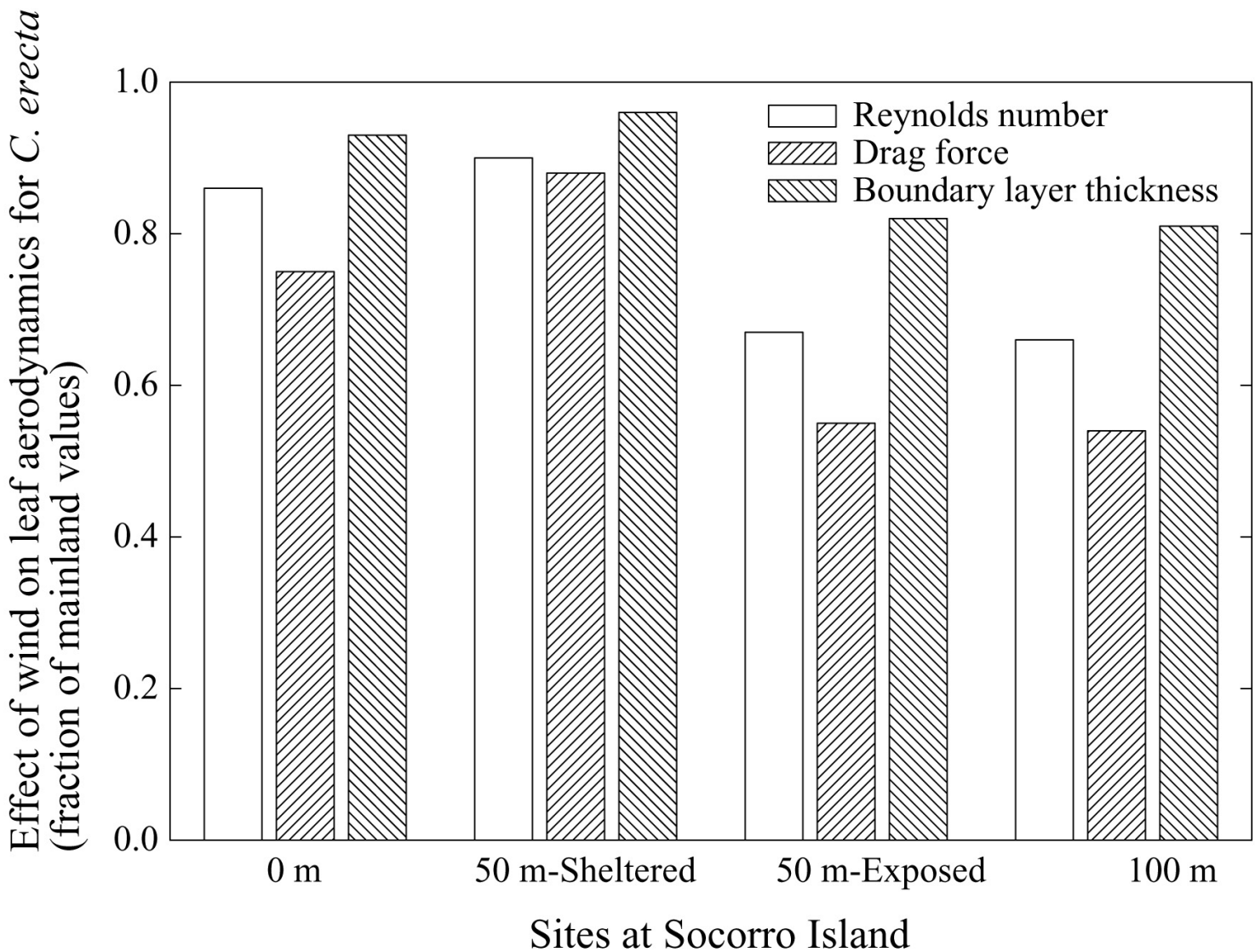

Fig. 4: Effects of wind on leaf aerodynamics for C.erecta from sheltered ("0 m", "50 m-sheltered") and exposed ("50 m-exposed”, "100 m”) sites from Socorro Island. Data, calculated as for Fig. 3, are presented relative to the values for C.erecta from La Manzanilla.

Efectos del viento en la aerodinámica foliar de C. erecta en sitios protegidos ("0 m", "50 m-sheltered") y expuestos ("50-m exposed", "100 m") de Isla Socorro. Los datos, que fueron calculados igual que en la Fig. 3, se presentan en relación a los valores obtenidos para C. erecta en La Manzanilla.

TABLE 2

Stomatal frequency and dimensions for Conocarpus erecta from La Manzanilla, Jalisco, Mexico. Data are means \pm SE $(n=5$ leaves $)$

Frecuencia y dimensiones estomáticas en Conocarpus erecta de La Manzanilla, Jalisco, México. Los datos son promedios $\pm \mathrm{EE}(\mathrm{n}=5$ hojas $)$

\begin{tabular}{|c|c|c|c|}
\hline Variable & Adaxial surface & Abaxial surface & P-value \\
\hline Frequency $\left(\mathrm{mm}^{-2}\right)$ & $14.1 \pm 0.8$ & $18.1 \pm 1.2$ & 0.024 \\
\hline Mean stomatal radius $(\mu \mathrm{m})$ & $9.1 \pm 0.26$ & $10.3 \pm 0.38$ & 0.031 \\
\hline Pore depth $(\mu \mathrm{m})$ & $6.6 \pm 0.30$ & $6.4 \pm 0.34$ & 0.671 \\
\hline
\end{tabular}




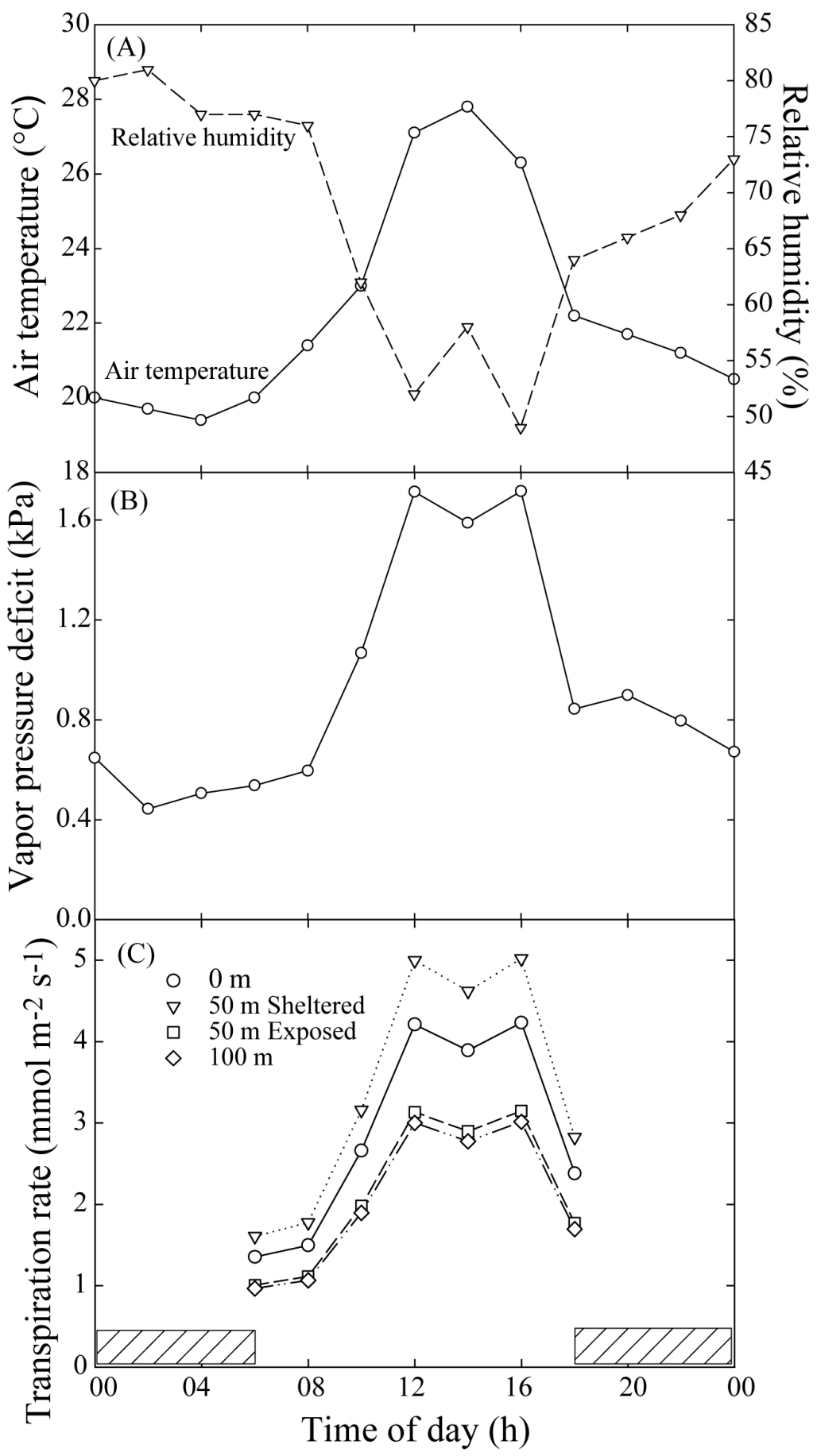

Fig. 5: Leaf water relations for C.erecta from Socorro Island. Air temperature and relative humidity (A) were measured on 17-18 May 1999 to determine the daily pattern of vapor pressure difference between the leaves and the surrounding air (B) and to calculate instantaneous transpiration rates (C) for plants at sheltered (circles, triangles) or exposed (squares, diamonds) locations. The hatched bars indicate nighttime, during which transpiration was assumed to be nil.

Relaciones hídricas en hojas de C. erecta de Isla Socorro. La temperatura y humedad relativa del aire (A) fueron medidas el 17-18 de mayo de 1999 para determinar el patrón diario de la diferencia de presión de vapor entre las hojas y el aire (B) y para calcular tasas instantáneas de transpiración (C) en plantas de sitios protegidos (círculos, triángulos) o expuestos (cuadros, rombos) al viento oceánico. Las barras rayadas indican la noche, durante la cual se asumió que la transpiración sería nula. 
trees from the exposed sites. Nevertheless, the petioles of $C$. erecta are shorter and less distinct from the leaf blade than they are for the other mangrove species (E. De la Barrera unpublished results). Leaves with a long petiole, such as those of $R$. mangle, tend to flutter less and experience less drag than those with short petioles (Vogel 1989). Moreover, the short petioles of $C$. erecta could also reduce the leaf's ability to become aligned with the direction of wind, hence becoming more prone to tearing (Vogel 1981, Cleugh et al. 1998). In this case, the fact that the leaves of $C$. erecta are also rather sclerophylous probably helps reduce fluttering and hence drag, as it dramatically occurs for a rigid plate compared to a flexible plate (Vogel 1989).

The high-wind environment under which $C$. erecta grows at the northern shores of Socorro Island appears to have driven morphological adaptations for this species. Reduction in size is a relatively common plant adaptation to wind (Whitehead \& Luti 1962, Nobel 1981, Voesnek $\&$ Blom 1996, Cleugh et al. 1998). The reduced tree height observed for $C$. erecta at higher elevations on Socorro Island as well as the leaf dimensions of this species presumably result from high wind exposure at least to some extent. Nevertheless, reduced tree height for mangroves can also be attributed to other adverse environmental factors such as nutrient availability (Feller 1996, Feller et al. 2003), salinity (Jiménez 1984), and water loging (Medina 1999). In addition, C. erecta is not the only mangrove found at a considerable distance from the ocean. A stand of Bruguiera gymnorrhiza occurs at $120 \mathrm{~m}$ inland at altitudes of up to $37 \mathrm{~m}$ on an island from the Indian Ocean (Woodroffe 1988). Nevertheless such trees can reach heights approaching $40 \mathrm{~m}$ and have a seasonal influx of fresh water. Thus, the distinct leaf aerodynamics observed at the island suggest an important contribution of wind as a driving factor for morphological adaptations by $C$. erecta.

The transpiration rates calculated here for $C$. erecta from Socorro Island was similar to rates previously reported for this species (Orozco et al. 1990, Snedaker \& Araujo 1998). A caveat to be considered here is that that calculations were based solely on stomatal frequencies of mainland plants. Thus, if the stomatal frequencies for island plants were different, the predicted gas exchange rates would be modified. In any case, actual measurements of gas exchange or biomass accumulation studies (e.g., using litter traps) would be necessary to determine plant productivity for $C$. erecta. Nevertheless, the approach utilized here does indeed illustrate plausible gas exchange responses to wind. Considering that transpiration can reflect plant productivity (Medina 1999, Sobrado 2000, Nobel 2005), the lower transpiration rates calculated for exposed locations than for sheltered locations on Socorro Island suggest a tradeoff between adaptations to mechanical stress and plant productivity. However, smaller leaves are not necessarily disadvantaged for harvesting light (Bragg \& Westoby 2002). Such small leaves often become thicker, therefore increasing the area of their light-harvesting mesophyll relative to the leaf's surface area (Nobel 2005). Also, a decrease in plant height or leaf size for plants exposed to wind, such as for $C$. erecta at Socorro Island, can be a hormone-mediated response to mechanical stress, leading to more robust plants (Voesenek \& Blom 1996, Cleugh et al. 1998).

Leaf morphology can provide information about plant ecological performance. For instance, by reflecting the plant's ability to harvest light (Bragg \& Westoby 2002), the nutrient status of the soil (Feller 1996), or, as illustrated here, specializations to high-wind environments. While the driving forces of evolution appear to act relatively faster on islands than on the mainland (Cody \& Overton 1996, Walter 1998), the adaptations observed for $C$. erecta are also likely to occur for mainland mangrove forests, especially at locations with high hurricane frequency. However, $R$. mangle, the largest and least streamlined of the mangroves considered here, usually occurs at the most exposed sites for multi-species mangrove forests (Medina 1999). To shed light on such apparent contradiction, experimental studies are needed that explicitly consider the importance of wind relative to other environmental and biological factors contributing to the dynamics of mangrove forests and the relative fitness of each individual coexisting species. For $C$. erecta from Socorro Island, further research should also consider whether its presence at $100 \mathrm{~m}$ in elevation, at a remarkable distance from the 
ocean, is an island adaptation or a mere reflection of the inherent distributional potential for this tropical species.

\section{ACKNOWLEDGEMENTS}

We thank funding from a Consejo Nacional de Ciencia y Tecnología (CONACyT) graduate fellowship, a "Stephen A. Vavra" Fellowship for Plant Sciences, and, during the preparation of the manuscript, a University of California Institute for Mexico and the United States (UCMEXUS) Postdoctoral Fellowship to EDIB, as well as an UC-MEXUS grant to HSW; six researchers from Universidad Nacional Autónoma de México (UNAM) who participated in the 1999 Scientific Expedition to the Revillagigedo Archipelago, especially Ms. Dalia Ayala; and the hospitality and field assistance of colleagues Rodrigo Esparza and Luis Fernando Alvarado, which were invaluable at La Manzanilla.

\section{LITERATURE CITED}

ARAUJO RJ, JC JARAMILLO \& SC SNEDAKER (1997) LAI and leaf size differences in two red mangrove forest types in south Florida. Bulletin of Marine Science 60: 643-647.

BALDWIN A, M EGNOTOVICH, M FORD \& W PLATT (2001) Regeneration in fringe mangrove forests damaged by Hurricane Andrew. Plant Ecology 157: 149-162.

BRAGG JG \& M WESTOBY (2002) Leaf size and foraging for light in a sclerophyll woodland. Functional Ecology 16: 633-639.

CLEUGH HA, JM MILLER \& M BÖHM (1998) Direct mechanical effects of wind on crops. Agroforestry Systems 41: 85-112.

CODY ML \& J McC OVERTON (1996) Short-term evolution of reduced dispersal in island plant populations. Journal of Ecology 84: 53-61.

COMISION NACIONAL PARA EL USO Y APROVECHAMIENTO DE LA BIODIVERSIDAD (1998) Límite nacional. Escala 1:250 000. Extraído del modelo digital del terreno. Instituto Nacional de Estadística, Geografía e Informática, Mexico City, México.

ELLISON AM \& EJ FARNSWORTH (1997) Simulated sea level change alters anatomy, physiology, growth, and reproduction of red mangrove (Rhizophora mangle L.). Oecologia 112: 435-446.

EVES H (1967) Mensuration formulae. In: Weast RC \& SM Selby (eds) Handbook and tables for mathematics: 7-19. The Chemical Rubber Company, Cleveland, Ohio, USA.

FELLER IC (1996) Effects of nutrient enrichment on leaf anatomy of dwarf Rhizophora mangle L. (red mangrove). Biotropica 28: 13-22.

FELLER IC, DF WHIGHAM, KL McKeE \& CE
LOVELOCK (2003) Nitrogen limitation of growth and nutrient dynamics in a disturbed mangrove forest, Indian River Lagoon Florida. Oecologia 134: 405-414

GRACE J (1974) The effect of wind on grasses: I. Cuticular and stomatal transpiration. Journal of Experimental Botany 25: 542-555.

HERNÁNDEZ-VÁZQUEZ S (2000) Aves acuáticas del estero La Manzanilla, Jalisco, México. Acta Zoológica Mexicana 80: 143-153.

JIMÉNEZ JA (1984) A hypothesis to explain the reduced distribution of the mangrove Pellicera rhizophorae Tr. \& P1. Biotropica 16: 304-308.

LARA-DOMÍNGUEZ AL \& A YÁÑEZ-ARANCIBIA (1999) Productividad secundaria, utilización del hábitat y estructura trófica. In: Yáñez-Arancibia A \& AL Lara-Domínguez (eds) Ecosistemas de manglar en América tropical: 153-166. Instituto de Ecología, Xalapa, Veracruz, México.

LEVIN GA \& R MORAN (1989) The vascular flora of Isla Socorro, Mexico. Memoir 16. San Diego Society of Natural History, San Diego, California, USA. 71 pp.

LUGO A \& SC SNEDAKER (1974) The ecology of mangroves. Annual Review of Ecology and Systematics 5: 39-64.

MEDINA E (1999) Mangrove physiology: the challenge of salt, heat, and light stress under recurrent flooding. In: Yáñez-Arancibia A \& AL Lara-Domínguez (eds) Ecosistemas de manglar en América tropical: 10-126. Instituto de Ecología, Xalapa, Veracruz, México.

MEDINA GM (1978) Memoria de la expedición científica a las Islas Revillagigedo: abril de 1954. Segunda edición. Universidad de Guadalajara, Guadalajara, Jalisco, México. 333 pp.

NOBEL PS (1981) Wind as an ecological factor. In: Lange OL, PS Nobel, CB Osmond \& H Ziegler (eds) Physiological plant ecology I: responses to the physical environment: 475-500. Springer-Verlag, Berlin, Germany.

NOBEL PS (2005) Physicochemical and environmental plant physiology. Third edition. Academic Press/ Elsevier, Burlington, Massachusetts, USA. 567 pp.

PASSIOURA JB, MC BALL \& JH KNIGHT (1992) Mangroves may salinize the soil and in soil and in so doing limit their transpiration rate. Functional Ecology 6: 476-481.

RICKLEFS RE (1979) Ecology. Second edition. Chiron Press, New York, New York, USA. 966 pp.

RUNDEL PR \& WM JARREL (1989) Water in the environment. In: Pearcy RW, Ehleringer J, Mooney HA \& PW Rundel (eds) Plant physiological ecology: field methods and instrumentation: 29-56. Chapman and Hall, New York, New York, USA.

SOBRADO MA (2000) Relation of water transport to leaf gas exchange properties in three mangrove species. Trees 14: 258-262.

TOMLINSON PB (1994) The botany of mangroves. Cambridge University Press, New York, New York, USA. 419 pp.

VOESNEK LACJ \& BLOM CWPM (1996) Plants and hormones: an ecophysiological view on timing and plasticity. Journal of Ecology 84: 111-119.

VOGEL S (1981) Life in moving fluids: the physical biology of flow. Willard Grant Press, Boston, Massachusetts, USA. 352 pp.

VOGEL S (1989) Drag and reconfiguration of broad leaves in high winds. Journal of Experimental Botany 40 941-948. 
WALTER HS (1998) Driving forces of island biodiversity: an appraisal of two theories. Physical Geography 19: 351-377.

WHITEHEAD FH \& R LUTI (1962) Experimental studies of the effect of wind on plant growth and anatomy. I. Zea mays. New Phytologist 61: 56-58.

Associate Editor: Luis Corcuera

Received March 5, 2006; accepted August 16, 2006
WIGGINS IL (1980) Flora of Baja California. Stanford University Press, Stanford, California, USA. 1,025 pp.

WOODROFFE CD (1988) Relict mangrove stand on last interglacial terrace, Christmas Island, Indian Ocean. Journal of Tropical Ecology 4: 1-17. 
